\section{Visión Electrónica Más que un estado sólido \\ https://doi.org/10.14483/issn.2248-4728}

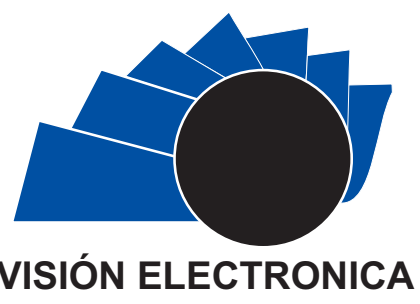

A Current Vision

\title{
Multi-agent system as support process of transplant of organs
}

\author{
Sistema multiagente como apoyo de procesos de trasplante de órganos \\ Félix Andrés Sánchez-Rivera ${ }^{1}$, Miguel Ángel Leguizamón-Páez ${ }^{2}, J h e s h u a$ Dannand \\ Jared Larrota-Alférez ${ }^{3}$
}

\section{INFORMACIÓN DEL ARTICULO}

Historia del articulo

Envviado: 01/08/2018

Recibido: 18/08/2018

Aceptado: 02/10/2018

\section{Keywords:}

Donation,

Geo- Java Agent Development

Framework (JADE),

Heart,

Intelligent Agents,

Localization,

Transplant.

\section{Palabras clave:}

Donación,

Geo- Java Agent Development

Framework (JADE),

Corazón,

Agentes Inteligentes,

Localización,

Trasplante.

\section{ABSTRACT}

This article is a review that leads to build a state of knowledge about Multi-Agent Systems based on Selection and Search (ISSA) applied in the search and selection of organ and tissue transplant recipients, emphasizing as a case study the heart, using Geo-location. In particular, this research analyzes technical, scientific and normative aspects of ISSA, between 2007 and 2017, in Europe (Spain) and Latin America (Colombia). A base line of systems based on Artificial Intelligence is thus obtained for the selection and search of transplant recipients, before a possible demand of the List of Persons Waiting for Donation (LED). From the above, solutions can be implemented reducing time in the allocation of organs taking into account their characteristics and compatibility: blood group, size, location criteria, among others, from one to several possible recipients. Finally, a technological solution model for Colombia is proposed.

\section{RESUMEN:}

El presente artículo es una revisión que conduce a construir un estado de conocimiento sobre Sistemas Multi Agentes basados en Selección y Búsqueda (AISB) aplicados en la búsqueda y selección de receptores de trasplante de órganos y tejidos, enfatizando como caso de estudio el corazón, utilizando Geo- localización. Particularmente, esta investigación analiza aspectos técnicos, científicos y normativos de AISB, entre el 2007 y 2017, en Europa (España) y Latino América (Colombia). Se obtiene en consecuencia una línea de base de sistemas basados en Inteligencia Artificial para la selección y búsqueda de receptores de trasplante, ante una posible demanda de Lista de Personas en Espera de Donación (LED). De lo anterior, se pueden implementar soluciones reduciendo tiempos en la asignación de los órganos teniendo en cuenta sus características y la compatibilidad: de grupo sanguíneo, tamaño, criterios de ubicación, entre otros, de uno a varios posibles receptores. Finalmente se propone un modelo de solución tecnológica para Colombia.

\footnotetext{
1BSc. In Telematic Engineering, Universidad Distrital Francisco José de Caldas, Colombia. Current position: Software Developer and Implementer Asesoftware, Colombia. E- mail: fsanchez@, asesoftware.com. ORCID: https://orcid.org/0000-0002-6880-2494.

${ }_{2}$ BSc. In Systems Engineering, Specialist in Information Systems Management, Universidad de Boyacá, Colombia. MSc. In Information and Communications Sciences, Universidad Distrital Francisco José de Caldas, Colombia. Current position: Professor at Universidad Distrital Francisco José de Caldas, Colombia. Email: maleguizamonp@,correo.udistrital.edu.co.ORCID: https://orcid.org/0000-0003-0457-0126.

sBSc. In Telematic Engineering, Universidad Distrital Francisco José de Caldas, Colombia. Current position: Moodle Administrator at Universidad Distrital Francisco José de Caldas, Colombia.Email: jdlarrotaa@,correo.udistrital.edu.co. ORCID: https://orcid.org/0000-0002-6938-1839.

Cite this article as: F. A. Sánchez-Rivera, M. A. Leguizamón-Páez and J. D. J. Larrota-Alférez, "Multi-agent system mas support process of transplant of organs", Visión electrónica, algo más que un estado sólido, vol. 1, no. 2, Special edition, july-december 2018. DOI revista: https://doi.org/10.14483/issn.2248-4728
} 


\section{Introduction}

Scientific advances in heart transplants make it possible for a large number of patients to benefit from this practice throughout the world. However, time is an important factor for carrying out a successful transplant since the heart has a life time after extraction to the donor, which is why it is required to reduce the time between donating the organ and the donor transplant. Although transplants can save thousands of lives and transform the quality of life of patients, many patients die or must continue with their treatment, since there are organs that have a limited life time reduce these probabilities [1].

In Colombia, according to the Colombian Institute of Health (INS), as of September 2016 there were 2,277 patients on the waiting list for organ transplants; of this figure, 24 patients, corresponding to $1.054 \%$ of the List of People Waiting for Donation (LED), require a heart transplant, [2].

On the other hand, geo-localization has become a tool to geographically locate any object in real time [3] using applications such as Google Maps for the suggestion of geographical routes, allowing an efficient mobilization; it even displays the route trace, the state of the road, accidents and vehicular flow, among others, [4]. Taking into account that most mobile devices have a Global Positioning System (GPS), this technology is affordable and at low cost for users who want to use it, then it is of vital importance in the Colombian case, [5].

In this document, then, an alternative is proposed to implement and develop medical decision-making by means of intelligent agents, where the results of the tests performed on the heart are analyzed, and from these, calculate, analyze and trace the best trajectory of displacement of the organ and / or patients, and subsequent notification to the patients of the LEDs, [6].

For the above, the document is structured as follows. Initially the methodology is presented; then a context study is carried out in front of the Intelligent Agents, Geo-Location and Normativity; later the technological analysis is shown and finally a proposal is outlined with its design and architecture based on Applied Intelligent Agents in Heart Transplant Receptors.

\section{Methodology}

In the last 10 years, research has been conducted on SMA in which the following categories stand out, according to the field applied: Intelligent Agents, GeoLocation, and Normativity; where Europe, Latin America and Colombia are world leaders. Due to the scarcity of information on the subject, a classification of the academic, scientific, journalistic content on this little explored field on which the organ selection process is based, will be useful to establish a baseline for research in the area.

For the exploratory study, the bibliographic search used the following databases: IEEE Xplore Digital Library, Springer Link, Scopus and SciELO Mexico. The references obtained range between 80 and 90, with the keywords used and corresponding to the categories. The endorsement of this methodology was obtained from experts from the Artificial Intelligence Research Group (GIAFT) of the Universidad Distrital Francisco José de Caldas. The Method by indices was used for the construction of the revision (vertebrate from a general index) [7], in which some categories and subcategories are established, illustrated in figure 1 and 2.

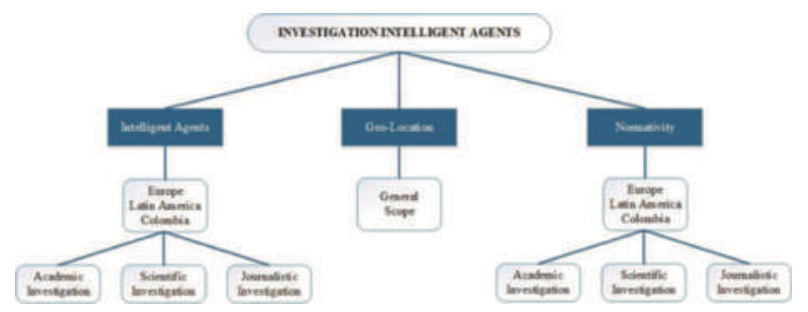

Figure 1. Investigation Intelligent Agents. Source: own.

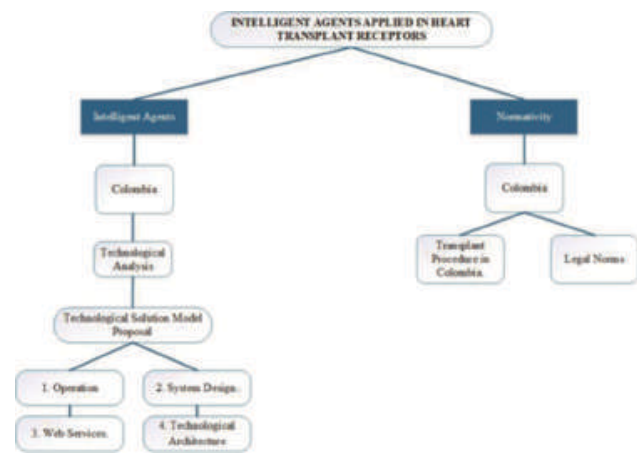

Figure 2. Intelligent Agents Applied in Heart Transplant Receptors. Source:own.

\section{Analysis of the Context}

According to the World Health Organization, around 17.5 million people died from heart disease, which represents 31 percent of all deaths worldwide. [8] Most cardiovascular diseases are due to heart disorders

\footnotetext{
${ }^{4}$ Geo-localization: Geo-localization is the ability to fix geographic coordinates to information by means of computer equipment. The generality of GPS technology in devices for personal use such as mobile phones and personal computers has allowed it to be within the reach of society. To obtain coordinates, the system is based on the simultaneous determination of distances by means of satellites. These distances are obtained from the signals transmitted by the satellites, which are received by receivers.

${ }^{5}$ Google Maps: It is a free service based on an application server of maps on the web that belongs to Alphabet Inc. Offers images of scrollable maps, as well as satellite photographs of the world and even draws the route between different locations.

${ }^{6}$ Intelligent Agent: It is a software entity that, based on its own knowledge, performs a set of operations designed to meet the needs of a user or another program, either on its own initiative or because one of them requires it. An intelligent agent is considered capable of doing anything or of perceiving an environment or environment through sensors and acting on it, through sensors; It also has the ability to communicate with other intelligent agents. Sometimes, these are developed as entities that constitute a system to solve a problem. 
where the most common are: myocardial infarction, ischemic heart disease, heart failure, sudden death, arrhythmias, congenital heart disease, diseases that support and can be treated effectively by means of a heart transplant that is an effective therapeutic solution for the aforementioned diseases, particularly in patients with terminal heart failure, [1].

In Europe between 2008 and 2012, Achieving Comprehensive Coordination in Organ Donation throughout the European Union (ACCORD), a project that achieved the objective of reinforcing the full potential of the Member States, made up of 23 Associates; the National Transplant Organization (Spain) acting as Project Coordinator in the area of organ donation and transplantation and which improved cooperation by contributing to the effective implementation of Directive 2010/53 / EU. Currently ACCORD is not in force, but managed: [9]

-To improve the information systems of the Member States on the donation of living organs.

- To implement practical collaborations between countries of the European Union for the transfer of knowledge, experience or tools in specific areas related to Directive 2010/53 / EU.

-To provide recommendations for future twinning initiatives in organ donation and transplantation.

In this context, with emphasis on Spain - the country with the highest donation rate in the world - donations are always made altruistically and the State covers the whole process, from the economic point of view, through the National System of Health. The Spanish donation model is an example to be imitated, in fact it is being implemented in a large part of the world. One of the most relevant aspects of this model is equity in access to transplantation, establishing that all citizens have the same right and the same possibilities of receiving it, regardless of their place of residence or any other personal situation. This is because the control of the National Network of Coordination and Transplants, establishes rigorous controls to verify the equality of all citizens, [10].

In Spain, there are two clinical criteria that are considered in the process: the donor / recipient compatibility, and the severity of the patient, giving absolute priority to the "Urgency $O$ " against the territorial assignment. If there is no "Urgency 0 ", the organs are assigned respecting the territorial criteria,
[11]. The transplant team is in charge of deciding, within their waiting list, which patient is the most suitable to receive the organ. Then, in Table 1, the number of transplants in Spanish cities is related in the period 2008-2013.

\begin{tabular}{|l|l|l|l|l|l|l|l|}
\hline Spain & & $\mathbf{2 0 0 8}$ & $\mathbf{2 0 0 9}$ & $\mathbf{2 0 1 0}$ & $\mathbf{2 0 1 1}$ & $\mathbf{2 0 1 2}$ & $\mathbf{2 0 1 3}$ \\
\hline Andalucía & Heart & 35 & 41 & 26 & 38 & 32 & 27 \\
\hline Aragón & Heart & 9 & 6 & 9 & 7 & 11 & 8 \\
\hline Asturias & Heart & 15 & 12 & 13 & 11 & 16 & 14 \\
\hline Cantabria & Heart & 19 & 14 & & 16 & 20 & 25 \\
\hline Castilla La Mancha & Heart & 0 & 0 & & & & \\
\hline Castilla and León & Heart & 11 & 13 & 8 & 5 & 57 & 4 \\
\hline Cataluña & Heart & 55 & 42 & 43 & 54 & & 52 \\
\hline Ceuta & Heart & 0 & 0 & & & & \\
\hline Extremadura & Heart & 0 & 0 & & & & \\
\hline Galicia & Heart & 24 & 21 & 23 & 18 & 25 & 20 \\
\hline Baleares Islands & Heart & 0 & 0 & & & & \\
\hline Canarias Islands & Heart & 0 & 0 & & & & \\
\hline La Rioja & Heart & 0 & 0 & & & & \\
\hline Madrid & Heart & 81 & 79 & 57 & 49 & 54 & 62 \\
\hline Melilla & Heart & 0 & 0 & & & & \\
\hline Murcia & Heart & 2 & 4 & 6 & 3 & 1 & 7 \\
\hline Navarra & Heart & 7 & 6 & & 5 & 5 & 8 \\
\hline Vasco Country & Heart & 0 & 0 & & & & \\
\hline Valencia & Heart & 34 & 36 & 32 & 31 & 26 & 22 \\
\hline
\end{tabular}

Table 1. Number of transplants in Spanish cities 2007-2013 [12].

There has been, according to the figures, an increase in the number of transplants in Spain, since its inception in the period 1984-1998, with little variability in the period shown, with a cut to 2013 , Figure 3.

\section{NUMBER OF TRANSPLANTS IN SPAIN 2007-2013}

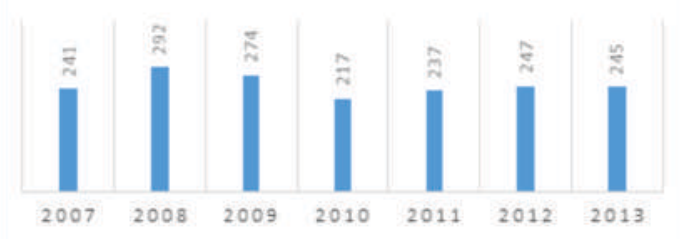

Figure 3. Number of transplants in Spain 2007-2013 $\left[{ }^{1} 2\right]$.

On the other hand, In Latin America in 2005, The IberoAmerican Donation and Transplant Council (CIDT) was created, which arises as a consequence of the agreements of the Heads of State and Government of the following Ibero-American and Caribbean countries: Argentina, Bolivia, Brazil, Chile, Costa Rica, Cuba, El Salvador, Ecuador, Guatemala, Honduras, Nicaragua,

\footnotetext{
Associates: Spain, Italy, United Kingdom, France, Bulgaria, Croatia, Cyprus, Czech Republic, Estonia, Germany, Greece, Hungary, Ireland, Latvia, Lithuania, Malta, Norway, Portugal, Poland, Romania, Slovak Republic, Slovenia.

${ }^{8}$ Directive 2010/53 / EU: On standards of quality and safety of human organs intended for transplantation. 
Mexico, Panama, Peru, Dominican Republic, Uruguay and Venezuela, with the objective of establishing measures to increase tissue and cell organ donation rates and increase each year the number of transplants and , therefore, decrease the waiting lists of patients.

In the above sense, the donation, extraction, processing, storage, distribution and implantation of human cells and tissues must adapt and respect the ethical principles and the Universal Declaration of Human Rights; additionally, advertising and promotional activities for the donation of tissues and cells of human origin must comply with the guidelines or legislative provisions in each country to ensure that this activity is carried out without profit, emphasizing that the extraction process should not interfere or compromise the health of the donor, establishing that tissues or cells should be distributed to centers or implant units authorized in accordance with the legislation of each country, finally, each country will define which or which is the competent health authority to carry out the tasks that they are entrusted in national legislation.

Then again, Chile has 3 laws, 4 Resolutions and 1 decree on organ donation and transplant: Law 19451, [13], determines who can be considered organ donors, where it specifies: Any person over 18 years of age will be considered as donor of its organs once deceased, with the exception of notifying it before a notary public that opposes the extraction of any biological component. Law 20988, [13], stipulates: only the removal of living organs for transplant purposes will be carried out when it is considered that it will not reasonably cause serious damage to the health of the donor and there are prospects of success to preserve life or improve the health of the donor receiver. Regarding the donation of unique organs from donors for cause of death, Resolution 784 of November 4, 2010, [14], establishes that the Health Center where the extraction is performed is at the same time, accredited as an Organ Transplant Center, so that the organ will be implanted in the same establishment, unless the recipient needs urgently the transplant and is in another Health Center. Regarding the case of peer organs, it is defined: that one of the organs will be implanted to some of the patients that make up the waiting list; and the other, that the Extraction Center will deliver this organ to the Public Health Institute, which will be distributed according to the National List of Recipients.

There again, in Colombia in 1985 the first heart transplant was performed to a 36-year-old man, allowing him to prolong his life in 22 months afterwards, [15]. Now, in the 1980 s there were no institutions that regulated and recorded the traceability of donation and heart transplant processes systematically [15], as the Red Donation and Transplant Group of the National Institute of Health with the Center has done. Transplant Regulator CRT established in 2004 by Article 5 of Decree 2493 of the same year, with the objective of guaranteeing the fulfillment and development of the functions established in the process of organ transplantation that is described in abbreviated form below, [16] Regarding the transplant procedure in Colombia, the following protocol is followed, [17]:

1. All donated and transplanted organs must comply with the current legal requirements and their control and surveillance carried out by the Health Secretariats and the INS National Institute of Health:

-Who made an organ, tissue or body fluids

-It must always be done for humanitarian reasons

-The IPS cannot charge for the medical processes that involve the donation or transplant.

2. Transplants are done by a specialized medical team trained in this field, in the Provider Health Institute (IPS) of third and fourth level that have facilities, equipment, procedures and equipment of the latest technology, ensuring health conditions in the surgical process.

3. The patient must be fit for a transplant program by following tests:

-Psychiatry.

-Social work.

-Psychology.

-Dentistry and Nephrology, Anesthesiology.

4. The compatibility between donor and recipient given by the blood group, genetic compatibility HLA (human leukocyte antigens), weight, height, age, diagnostic and paraclinical studies and other factors by technical-scientific criteria is required.

5. To be enrolled in the waiting list and be eligible.

6. According to the state of the patient's disease, the state of urgency for transplantation was determined.

7. To determine the existence of an organ donor.

8. To apply medical procedures that ensure the viability of the organs removed for

\footnotetext{
${ }^{9}$ Organ transplantation: Organ transplantation is considered a medical treatment that offers excellent results in the quality of life of people, in addition to prolonging it by means of the transplantation of diseased organs, tissues and cells by those of a donor.
} 
transplantation and that determine compatibility with list recipients.

9. To use the geographical location of the donor and the recipient that allows to preserve in optimal conditions the organ to be transplanted in a prudent time.

10. To notify potential recipients, by telephone or by mail, to approach the medical center to perform compatibility tests.

11. The Donation and Transplant Network has a record of the traceability, follow-up and audit of the entire process until its transplant.

\subsection{Legal Regulations}

The European Union in favor of regulating, in 2015 taking up the technical requirements for coding human cells and tissues of Directive 2004/23 / EC of the European Parliament and of the Council, of March 31, 2004 - decides to require the States members that guarantee the traceability of human cells and tissues from the donor to the recipient and vice versa, and establish a unique identifier that applies to tissues and cells distributed in the Union (European single code) that contains information on the main characteristics and properties of said tissues and cells, [18].

Particularly in Spain, the ONT, as the entity that controls and is in charge of developing the functions related to the obtaining and clinical use of organs, tissues and cells, issued the Royal Decree-law 9/2014 of July -with a total of 38 articles- established the quality and safety standards for the donation; the most relevant are: can only be obtained from cells and tissues of a living person if the donor is of legal age, in case it is a cadaveric donor the extraction can be made if the person had not left an express record of their opposition, according to the provisions of article 11 of Law 41/2002, of November, in the case of minors or people with judicially modified capacity, their relatives will have the decision to oppose the donation or not, [19].

For example, in Spain, the import, export and transit of these cells and tissues are allowed, if only: there is sufficient availability of said cells and / or tissues in national tissue establishments; that there is a medical reason that justifies the exportation, that the import and export requests of cells and tissues are directed to the National Transplant Organization where the fate of the cells and tissues is specified; all this must be specified in a certificate issued by the ONT, [19].

On the other hand, in Colombia before 1988 there was no regulation to regulate the process of donation and transplants. In this year the first regulations are legislated with reference to the donation of organs by the Congress of the Republic; however, previously if a person in life did not object to the removal of organs and / or tissues from his body after his death, and his relatives within four hours after death or brain death did not express their opposition, he would be treated as a donor (Law 73 of 1988 Article 2), [20].

Finally, by February 2017, Law 1805 of 2016 on organ donation [21] came into force, with 25 articles among which it is proposed: all Colombians of legal age will be organ donors, unless in life they state that they do not wish to be and their relatives cannot prevent such a decision. In this way, it is intended to encourage the donation of organs in Colombia, increasing the demand to counteract diseases, [22]. With respect to patients, in 2014 and 2015 there was a variation in the number of patients in LED; Now, with Law 1805 of 2016, a decrease in the number of patients in LED is projected in the coming years, table 2 and 3.

\begin{tabular}{|l|l|l|}
\hline Anatomical Component & $\begin{array}{l}\text { Waiting list status } \\
\text { December 31, 2014 }\end{array}$ & Waiting list status December 31, 2015 \\
\hline Kidney & 1991 & 2015 \\
\hline Liver & 118 & 82 \\
\hline Heart & 27 & 20 \\
\hline Lung & 16 & 14 \\
\hline
\end{tabular}

Table 2. Number of Patients in LED 2014-2015

$$
\text { [23]. }
$$

\subsubsection{Technological Analysis}

At international level there are advances in the development of software with intelligent agents in the field of medicine that have contributed to this article: one of the first with Intelligent Agents was in 1999 in Granada Spain, there they identified, defined and classified the different types of intelligent agents that an SMA Multi-Agent System can have: cooperatives, mobile agents, intelligent search agents, query agents, database agents, database query agents and user agents among others. This contribution has contributed to the development of technological projects with the aim of creating tools to support decision-making in the search and selection of organs for transplants, [23].

Thus, Spain, being a world leader in organ donation, developed a prototype with Intelligent Agents in the

\footnotetext{
${ }^{10}$ Organ Donation: Organ donation consists of taking healthy organs and tissues from one person to transplant them into others. According to the Colombian Ministry of Health "That the organs of a donor can save or help up to 55 people." The organs that can be donated are: Internal organs: kidneys, heart, liver, pancreas, intestines, lungs, among others. Tissues: Skin, Bone - bone marrow, cornea, blood vessels, heart valves, cartilage and tendons. 
medicine area where each actor of the system is represented: organ banks, hospitals, donor, recipient, among others, [24]. It is not simply a matter of collating the data and responding quickly and efficiently, but also analyzing clinical issues: urgency of the transplant, patient's age, risks, the Agents resolve them in minutes, this allows the time of allocation of the organs to be reduced from hours to minutes. Transplants that would normally be done in an average meeting, this project was carried out with the Hospital de Sant Pau (Barcelona), [25].

\begin{tabular}{|l|l|l|l|l|}
\hline $\begin{array}{l}\text { Type of } \\
\text { Organ }\end{array}$ & $\begin{array}{l}\text { Total } \\
\text { Transplants }\end{array}$ & $\begin{array}{l}\text { Cadaveric } \\
\text { Donor }\end{array}$ & $\begin{array}{l}\text { Genetically Related } \\
\text { Living Donor }\end{array}$ & $\begin{array}{l}\text { Living Donor } \\
\text { EmotionallyRelated }\end{array}$ \\
\hline Kidney & 768 & 642 & 116 & 10 \\
\hline Heart & 57 & 57 & 0 & 0 \\
\hline Liver & 227 & 197 & 30 & 0 \\
\hline Lung & 17 & 17 & 0 & 0 \\
\hline
\end{tabular}

Table 3. Total transplants by type of organ VS type of donor, Colombia, to November 2015 [26].

At an international level there are advances in the development of software with intelligent agents in the field of medicine that have contributed to this article: one of the first contributions with Intelligent Agents was in 1999 in Granada Spain, by Pedro Hípola and Benjamín Vargas- Quesada identified, defined and classified the different types of intelligent agents that an SMA Multi-Agent System can have: cooperatives, mobile agents, intelligent search agents, query agents, database agents, database query agents and User agents among others. This type of support has contributed to the development of technological projects with the aim of creating tools for decision support, in search processes and selection of organs for transplants, [26]. Spain being a world leader in organ donation, developed a prototype with Intelligent Agents in the medicine area where each actor of the system is represented: organ banks, hospitals, donor, recipient, among others, [24]. It is not simply a matter of collating the data and responding quickly and efficiently, but also analyzing clinical issues: urgency of the transplant, patient's age, risks, the Agents resolve them in minutes, this allows the time of allocation of the organs to be reduced from hours to minutes. Transplants that would normally be done in an average meeting, this project was carried out with the Hospital de Sant Pau (Barcelona), [25].

Towards 2001, in Tarragona (Spain) artificial intelligence techniques were implemented to provide an equipment of operating rooms and surgical instruments for quality organ transplants and in an efficient response time by the system, this advance allowed to generate the necessary logistics avoiding delays that can be harmful at the time of a transplant. In this project an SMA was employed, in charge of selecting the operating room and the surgical elements and notifying the medical personnel of the procedure, [27]. In that year another SMA was also created in accordance with the national legislation of Spain with the aim of promoting transparency in the selection process of organs where all the data corresponding to hospitals, patients on the transplant list, in an Intelligent System was collected. The Decision Support to coordinate the Spanish activity in organ transplants. Using the communication and negotiation layers offered in a distributed environment in which each agent is responsible for a specific process, the transplant coordination, the receiver required during the transplant coordination process. Finally, the SMA makes the system easy to adapt to structural changes based on organizational policies, and that extends to a frame of reference of its own, [28].

Later, in 2014, an Artificial Neural Network (ANN) was created in Cordoba for the medical decision-making process, whose objective was donor-recipient (DR) pairing in Liver Transplants (LT) and to compare the scores (MELD, D-MELD, DRI, P-SOFT, SOFT and BAR), by means of graft survival models, a rule-based system, statistical analysis. Which included 64 variables of donors and recipients of a set of 1003 LT by means of a multicenter analysis in 11 Spanish hospitals. Optimum results were obtained for the NN-CCR Positive Survival Model and the NN-MS Negative Loss Model, with the best performance to predict the probability of graft survival (90.79\%) and loss (71.42\%). for each DR pair, [29].

In 2016, following in Spain, the Multi-Agent System Group (GruSMA) of the Rovira i Virgili University, conducted an investigation on SMA Carrel + , which uses new agent-based argumentation techniques to reduce the number of organs rejected for transplant, even if hospital experts think organ is not feasible for example, due to the donor's smoking history, it allows to solve medical problems in which the required knowledge is essential, for example, can collect data from patients assigned to different doctors, institutions through distributed systems in electronic health. Some agents are mobile within an electronic network to obtain, analyze, filter, customize and present user data as required, also agents can autonomously model entities, for example, different possible recipients of an organ transplant or hospital assignment In the same way, agent-based systems can introduce security mechanisms that guarantee the confidentiality and privacy of sensitive data, such as electronic medical records taking into account security is a main concern of any SMA, [30]. 
Then again, now in Asia, in Taiwan in 2010 a novel proposal was created with a focus on the use of OMAS ontologies, with interaction in the process of matching applied to health, presents alternatives through expert knowledge in the nutritional field, a doctor that includes a personal knowledge agent, a diffuse inference agent and a semantic generation agent, to evaluate diets, with the possibility of creating nutritional tables for common Taiwanese foods. The system asks users to enter the food they eat, the ontology of food and the ontology of the personal profile. They are built by experts in the domain using FML diffuse markup language. OMAS semantically analyzes the state of the diet of the users based on the pre-constructed ontology; by using semantic analysis, users can obtain health information about what they eat, which can lead to a healthy lifestyle. The experimental results show that the proposed approach works effectively, [31].

On the other hand, in 2016 a group of German scientists carried out research on SMA applied in the health care field where five subdomains and three systems are evaluated in each subdomain. A set of common characteristics of these systems has been extracted and compared, analyzing the results and the deficiencies of the systems. The research has provided recommendations for SMA applied in the field of medical care, [32].

Likewise, a SLD105 proposal is generated with SMA, where a general architecture for the construction of SMA is defined, focused on the health sector, and using technologies and tools in accordance with the free software policies of the country, through the MasCommonKads methodology, whose main focus is the construction of intelligent systems, as agentoriented modeling language AgentUML AUML, which is supported by the Drools Expert 5.4.0 inference engine, PostgreSQL 9.1 as a database management system, the Enterprise Architect 7.1 tool, and the JADE agents platform 4.1. The integration of them provided a complete design of Multi-Agent Systems in the health sector, [33].

Meanwhile, in Berlin Charité University Hospital, provided a set of data: as tests, laboratory results and diagnoses for patients who suffered renal failure and who got an organ transplant or are still waiting for one. With the aim of developing a system to predict the sequence of events recorded in the digital medical history of each patient, and thus develop a metadata for a future support system for clinical decision making through statistical modeling and combination with model predictors of neural networks, using machine learning approaches that are based on a combination of embedding of entities and events in a multidimensional latent space, [34].

Returning to the work of the Research Group on Artificial Intelligence Departament d'Enginyeria Informàtica i Matemàtiques of the Universitat Rovira i Virgili URV, it presented a multi-agent architecture that supports the processes of transplantation and that is compatible with Spanish legislation. The proposal establishes an SMA, which is structured in 4 levels: national, zonal, regional and hospital, this last level, are the Agents corresponding to hospitals with transplantation capacity. Each Hospital Agent is in turn an SMA that manages the information of patients and organs donated from this hospital and where a local coordinator selects a recipient to an available organ, [35]. Agents from different hospitals under the transplant system cooperate and provide support to the coordinator following the parameters established by the National Transplant Organization, ONT, [36].

From another perspective, in the United States at the end of 2009, a study was advanced by means of a methodology based on data mining as a proposal to find other compatibility factors between the donated organ and the patient, which helped to better predict the survival of heart and lung transplants. Additional system took into account a considerable data set 16.604 with 283 variables to create predictive models based on machine learning, extract the predictive factors, then apply the three different methods of variable selection: First, machine learning methods using trees decision, neural networks, logistic regression, Second variables defined by experts based on the literature review, and third common sense based on the interaction variables, to be considered before an organ transplant, with the general objective of improving the prediction of the results after heart and lung transplantation when proposing an integrated data extraction methodology, [37].

In this same country, in 2000, in Portland, Oregon, a study was carried out to develop a technology based on artificial intelligence that could effectively classify the cardiac risk in the candidates for kidney transplantation, by means of an algorithm that formed an expert system, during a 4-year follow-up period, yielding a sensitivity of $82 \%$, a specificity of $77 \%$ and an accuracy of $78 \%$. The input to the neural network consisted of clinical variables and test data showed that a network of experts constructed from clinical risk factors obtained an accuracy of $89 \%$ in the prognosis of cardiac mortality among candidates for renal transplantation during a period of follow-up of 4 years, [38].

By February 2017, in the same country, a research was 
developed in the processing of images and automatic learning tools with the aim of automatically predicting cardiac rejection, improving the care of patients with heart transplants. The typing of cardiac rejection by means of myocardial Endo biopsies requires the experience of the pathologist, afterwards the histopathological images are examined manually in the microscope, which can be expensive, takes time and is prone to errors.

On the other hand, the implementation of digital image processing allows digital pathology, which is equipped with: Automatic learning classification algorithms, random search, support vector machine, logistic regression and neural networks can be applied to classify a new image based on training data. The study demonstrated the feasibility of applying a deep neural network to predict cardiac rejection, [39].

Finally, in Colombia, documentary review investigations on the applications of Agents and MultiAgent Systems used in medicine and health services have been carried out, based on the criterion of comparison of international methodology and architecture, one of the research projects was based on analyzing the chain of care of patients since they make their appointment, or have an emergency until they are in recovery at home. Showing the importance of Agents and Multi-Agent Systems in supporting this process, so that they can enter the development of prototypes with Intelligent Agents and Multi-Agents in telemedicine and Health services for the benefit of the Society, [40]. As indicated in the previous section, Colombia handles a receiver selection process that is not done with the help of any kind of software, it is only based on the registration of the transplants performed and the patients in LED, which has meant that the people waiting for a transplant, increase the possibility of deterioration, due to prolonged waiting times and the little development of computer tools in the area of medicine, [35].

For all the above, each of the aforementioned investigations has provided information to propose a model with Intelligent Agents for the selection and search of heart transplant recipients. Currently in Colombia a donation of heart is presented, there are several patients for transplantation registered in the LED with possibilities of being selected, generating difficulty to determine who will be the beneficiary. From here on, an alternative for the effect will be established.

\section{Proposed Alternative}

The architecture proposed for the logistics of heart transplantation is based on Intelligent Agents, Web Application, Maps JavaScript API and several Support Modules that are detailed below in the architecture:

Java: It will be the programming language to be used, taking into account that it will allow security and adaptability to all types of devices.

Oracle: It will be the database engine, because it is multiplatform, and will handle the relational model with high availability and scalability standards.

Maps JavaScript API: API for the calculation of GPS routes, by Google support in its infrastructure offering its calculation potential in Geo-localization.

SOAP Web Services is proposed for the communication of the following modules:

Registry Module: Responsible for collecting patient information in the LED and the compatibility results of the donated organ.

Search Module: Check the database of the LED and compile the information according to the established filters, conferring it to the Intelligent Selection Agent for its respective analysis and selection.

Geo-location module: Web Service responsible for consulting the Maps JavaScript API to map the best route of the donated organ and / or the selected patient for the transplant.

Notification module: It allows to notify by means of Text to Speech in telephone call, e-mail, text messaging, to the person who has been selected and where to go. The JADE Intelligent Agents container will have as the backbone of the system, E.S.B Enterprise Service Bus, since it is responsible for managing the communication between the entire system: Modules, Web Service and Intelligent Agents. [41]

Intelligent Search Agent: Check and collect the information provided by Maps JavaScript API, of possible routes, for the transfer of both the organ to be transplanted and the recipient to the meeting point where the transplant will be performed.

Intelligent Selection Agent: Selects the candidate of the LED by means of heuristic searches with a higher percentage of compatibility for the transplant.

\footnotetext{
${ }^{11}$ Java Agent Development Framework JADE): It is an open source middleware developed by Telecom Italia in 2000, used for the development of SMA Multi-Agent System, which can be run simultaneously in several systems, forming a platform that provides class libraries, through inheritance and stakeout of actions to create or destroy agents, by means of a container with the different types of agents: Directory Facilitator DF, with the function of providing availability of agents of the directory and Agent Management
} 


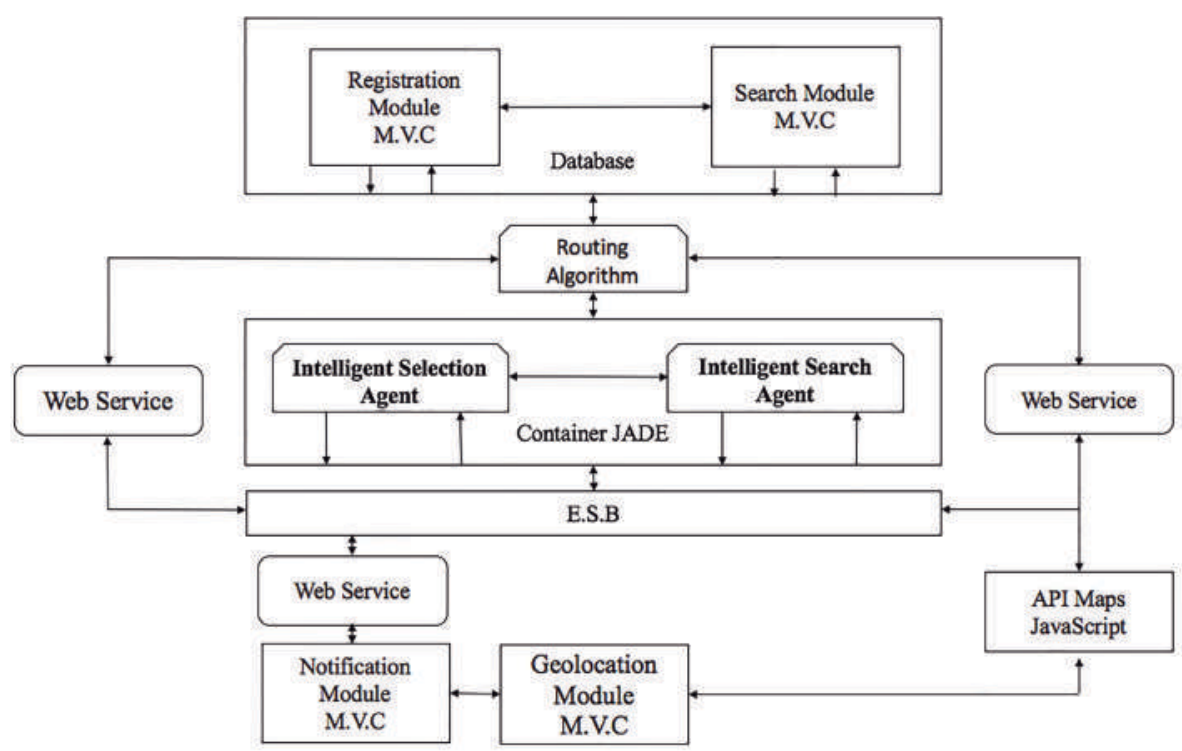

Figure 4. Development Architecture. Source: own.

The development architecture is considered, emphasizing its connectivity among the actors.

Therefore, the communication between the Intelligent Agents, the API, and the notification module will provide a solution separating the problem in the following processes:

1.Analysis of compatibility data.

2.Coordination of routes.

3.Alert notice of movement of the organ and / or patient.

4.Registration of selection exams.

5. Transplant notification to the beneficiary.

6.Upload of the transplant result information.

Figure 4, indicates the development architecture.

\subsection{System Design}

The system will be integrated by the JADE container and a sub-system of modules composed of the following modules: Registration, search, Geo-location, and notification.

The communication between the Intelligent Agents of Selection and Search, the container JADE and the modules will be carried out through asynchronous messaging, that is, the Intelligent Agents will send the message and the recipient will not need to be available at the same time, Figure 5.

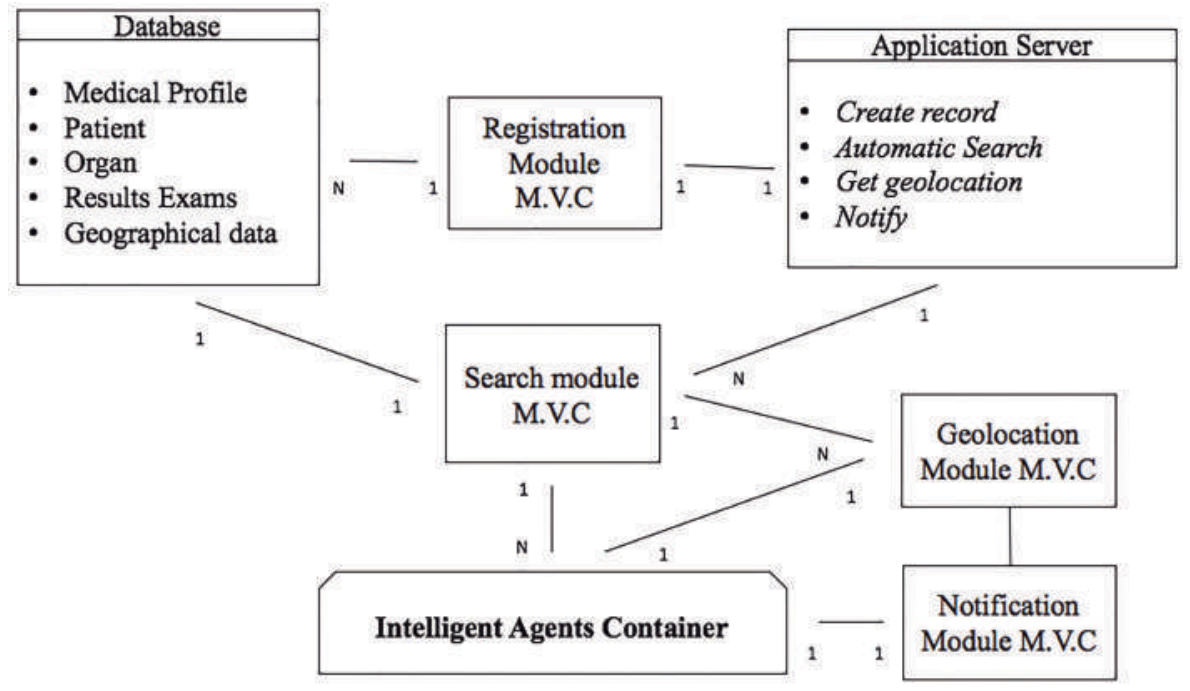

Figure 5. Diagram of communication of Intelligent Agents and Modules. Source: own. 
Architecture JADE, shown in Figure 6.

The system will have a container of Intelligent Agents where the Intelligent Selection Agent, Search Agent, AMS, DF is located. The container has the following services.

AMS Agent Management System: Will guarantee that each Intelligent Agent has a unique name, will have the autonomy to create and eliminate Agents that are in the container if it is required.

DF Directory Facilitator: It will allow to find other Agents, facilitating the services that they require by the Agents.
CT Contain table: Will store the record of references of objects and transport addresses of all the nodes of the system.

GATD Global Agent Descriptor Table: It will have the global record of all Intelligent Agents, including their current status and where they are.

LATD Local Agent Descriptor Table: It will have the local registry of all Intelligent Agents, including their current status and where they are.

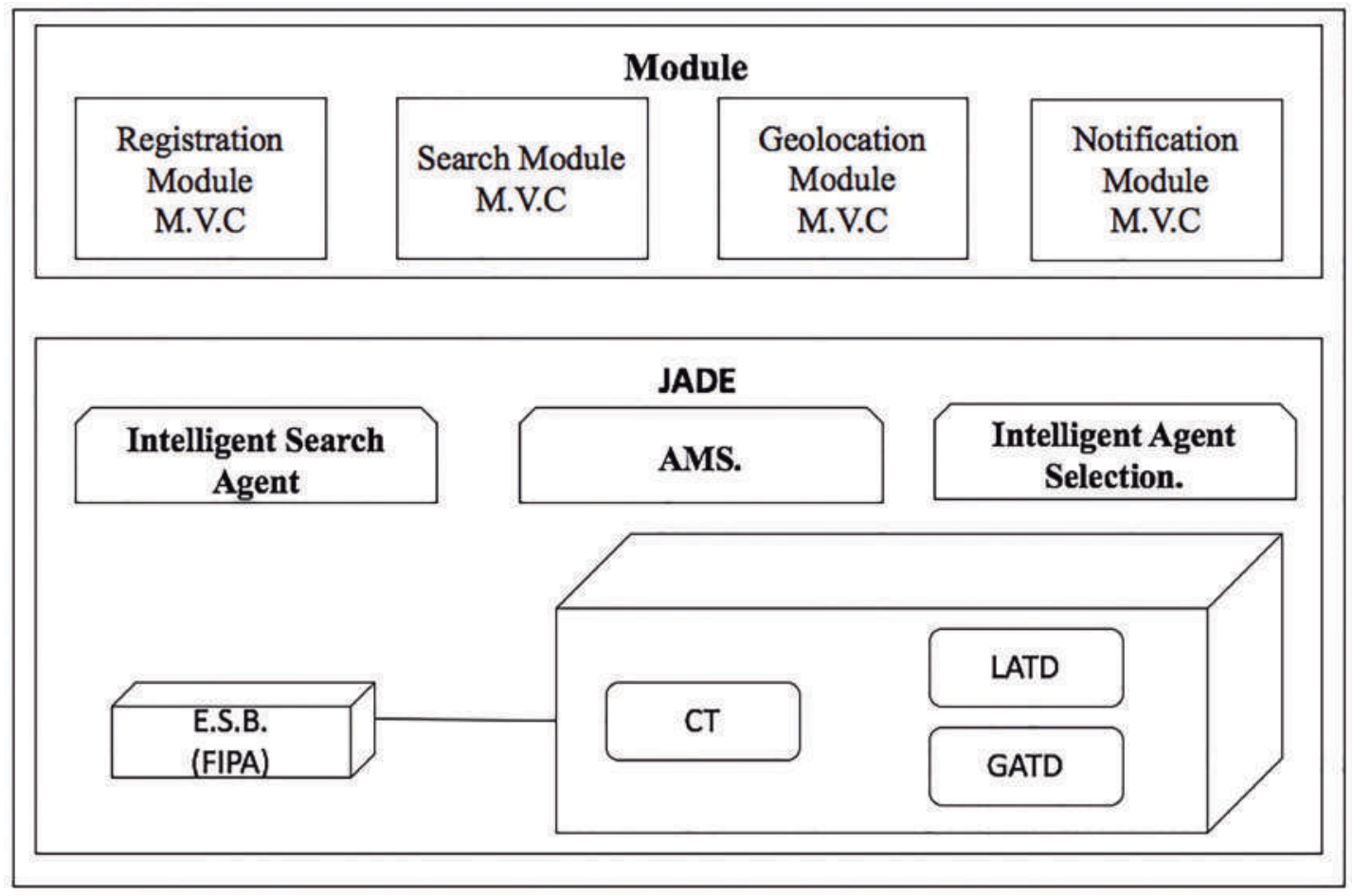

Figure 6. Diagram container JADE and Modules. Source: own.

The Selection Agent will analyze the results of the examinations performed on the organ based on the size, type of tissue and weight, among others, comparing the examinations performed to the patients, according to the LED nationwide that will be housed in the servers Ministry of Health, where the blood type will be recorded, tissue samples Biopsy to rule out cancer cells, urinalysis, evaluation of the structure and function of the heart by sound waves Echocardiogram, assessment of the electrical activity of the organ, revision of vessels blood by injecting a colorless liquid dye for radiographs. Cardiac Catheterization.

If it happens that more than one patient has the same level of compatibility and / or pregnancy, the Intelligent Selection Agent, Figure 7, will consider the route analysis by the Search and Maps API JavaScript. This procedure will also apply if only the Intelligent Selection Agent will produce a candidate. 


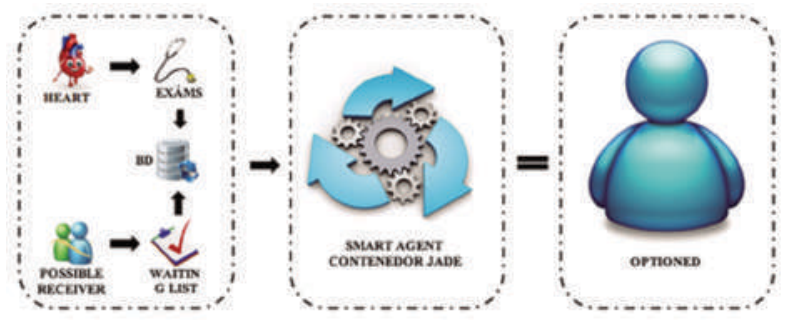

Figure 7. Intelligent Agent Selection. Source: own.

The Geo-location will offer an innovative and efficient solution through the Maps JavaScript API. This will inform the displacement options between two points: Origin and destination, which will be used by the Intelligent Search Agent, who will consult and collect the information to determine the feasibility and the coordination of the transfer of both the organ to be transplanted and the receiver. to the meeting point where the transplant will be made. The above considering the lifetime of the organ, which is 3 to 5 hours after being donated, which is crucial to perform a successful transplant, [42].

The API will have the function of calculating and plotting possible trajectories of displacement, Figure 8, suggesting the best route that both the organ and the donor can have, considering that:

1.The distance is less in distance and the time is longer taking into account traffic jams, closed roads, maintenance of roads, among others.

2.The route is very distant and the time is longer.

3. The road is greater in distance and the time is shorter, in the case that the

4. The shortest route presents slow traffic.

The above will apply for terrestrial displacements.

As a matter of fact, it will be fed from the longitude and latitude coordinates of the IPS where the donated heart is and from the possible beneficiaries of the heart transplant.

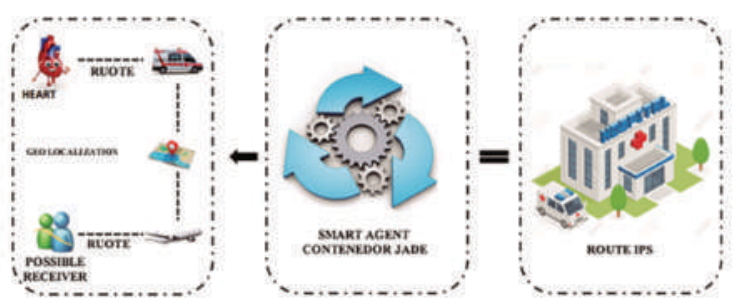

Figure 8. Intelligent Search Agent. Source: own.

There will be three possible scenarios for a better route: First, that the organ is in a third or fourth level IPS to perform the procedure and only the patient selected by the Intelligent Selection Agent will have to move to the coordinates where the transplant procedure will be performed.

The second scenario contemplates the possibility that the organ has to be transferred to a higher-level IPS, because the initial medical center does not have the tools to perform the surgical procedure, in addition, the transfer of the patient to the higher-level center will be required. It must be taken into account that in Colombia there are 25 IPS eligible for transplants, [43].

In the last scenario, only the organ will have to be transferred to an IPS suitable for the transplant where the patient is, either for reasons of hospitalization or clinical monitoring.

Finally, the notification module will inform the receiver that "Mr. (a) name of the patient you have been selected to perform the heart transplant, please urgently approach the IPS, the IPS name, address". This will be done in real time by the different means of information previously registered by the patient: Email, telephone and / or text message to the CRT. It would also notify the IPS with a message "IPS Name has programmed the heart transplant procedure for the DD / MM / YYYY, HH: MM".

\subsubsection{Web Services}

The system will have a series of SOAP web services that offer different operations, to the following modules: Registration Search, Geo-location and Notification, giving access to the WSDL file, consisting of an XML file that contains the functions according to the request for each module and the list of operations available to make the corresponding request.

\subsubsection{Technological Architecture}

The medical board will have systematic support in the cases of study, because the system will perform the assessment and subsequent selection of the recipient, through the Intelligent Selection Agent analyzing the results of the examinations performed on the organ thanks to the Multi-Agent architecture.

The Intelligent Search Agent that will use Maps JavaScript API, to plot the best route making this proposal viable because there is a latent need to systematize the process of route coordination based on Geo-location criteria and the time of life of the heart after of your donation to calculate the search perimeter. The system seeks to provide in the transplant process, the notification of the status of the transplant requested in real time to the selected patient, by more 
than one means of communication which allows for better control of calls, text messages, emails leaving traceability of communication event.

This proposal intends to materialize in the medium term, through medical knowledge, technological innovation and with the consensus of society in order to contribute in possible solutions to the problems in the heart transplant process, with the possibility of progressively encompassing each one of the donor organs in the system.

\section{Conclusions}

The documentary research led to propose a model of technological solution for Colombia, by using heuristic searches in order to select the possible receiver.

Intelligent Search Agents will use the Maps JavaScript API to calculate the route of the donated organ and / or the recipient to the health provider IPS and will communicate with the Notification module, which will send the corresponding messages of the possible transplant. This interaction will be possible thanks to the software architecture model Enterprise Service Bus, which will be in charge of managing the communication between the actors of the system.

As in Europe, research in SMA is constant, given that research material is evidenced within the latter, in the case of Latin America the majority of research has developed prototypes using SMA in areas related to medicine.

The article establishes a basic proposal for future research and / or developments that are to be carried out within the scientific, social or business educational sphere.

In perspective, the expectation of this proposal will be implemented with the objective of carrying out the necessary tests, which will help for the development in medical processes using Intelligent Applied Agents in Heart Transplant Receptors.

\section{References}

[1] R. Sánchez, “Trasplante de corazón”, Revista de investigación clínica, vol. 57, no. 2, 2005, pp. 333337.

[2] El Espectador, "Hay 2.277 pacientes en lista de espera de trasplante de órganos en Colombia", [ O n l ine ]. Avail a ble a t : https://www.elespectador.com/noticias/salud /hay-2277-pacientes-lista-de-espera-detrasplante-de-org-articulo-660418.
E. Rodríguez-Benito, "La Geolocalización, Coordenadas hacia el Éxito", II Congreso Internacional Comunicación 3.0”, Salamanca, España, 2018,pp. 7-12.

[4] Google.com, "Condiciones del servicio de Google - Privacidad y condiciones”, 2018. [O n line ]. Available a t: https://www.google.com/intl/es419/policies/terms/.

[5] Control \& strategias, "BIG Data, movilidad y geolocalización”, Revista Ctrl, no. 597, 2013, pp. 76-78.

[6] C. Martínez-Barrera, "Agentes de Software móviles", Nómadas, no. 15,2001, pp. 281-294.

[7] O. Londoño-Palacio, L. Maldonado-Granados and L. Calderón-Villafáñez, "Guía para construir estados del arte”, 2016, pp. 25-33. [ O n line ]. A vail a ble a t : http://iconk.org/docs/guiaea.pdf.

[8] El Tiempo, "Llaman a los colombianos a cuidar su corazón”, 2018. [Online]. Available at: http://www.eltiempo.com/vida/salud/lasenfermedades-cardiovasculares-son-una-delas-principales-causas-de-muerte-encolombia-33992.

[9] Accord, "Objectives", 2018. [Online]. Available at: http://www.accordja.eu/objectives.

[10] Organización Nacional de Trasplantes, "Donación”, España, 2018. [Online]. Available at:

http://www.ont.es/informacion/Paginas/D onaci\%C3\%B3n.aspx.

[11] Organización Nacional de Trasplantes, "Trasplantes", España, 2018. [Online]. Available at:

http://www.ont.es/informacion/Paginas/Tr asplante.aspx.

[12] Organización Nacional de Trasplantes, "Datos Históricos Donación y Trasplante España”, España, 2018. [Online]. Available at: 
[13] Biblioteca del Congreso Nacional de Chile, "Ley 20988", Chile, 2017. [Online]. Available at: https://www.leychile.cl/Navegar?idNorma $=1$ 100117 \&idParte $=0$.

[14] Biblioteca del Congreso Nacional de Chile, "Resolución 784", Chile, 2010. [Online]. A v a i l a ble a t : https://www.leychile.cl/Navegar?idNorma=1 $\underline{019044 \& \text { idParte }=0 .}$.

[15] Hospital San Vicente Fundación, "40 años del primer trasplante de órgano en Colombia", 2018 . [O O n line]. Available at: http://hospitaluniversitario.sanvicentefundaci on.com/index.php/comunidadonline/noticias/107-noticias-del-hospitaluniversitario/648-40-anos-primer-trasplantede-organo.

[16] Secretaría Distrital de Salud, "Política de donación de órganos, tejidos y células con fines de trasplante e implante”, Bogotá, 2012, pp. 830 . [Online]. Available at: http://www.saludcapital.gov.co/Polticas\%20e n\%20Formulacin/POLITICA\%20DE\%20DO NACION\%20DE\%20ORGANOS,\%20TEJID OS\%20Y\%20CELULAS.pdf.

[17] Instituto Nacional de salud, "El Instituto Nacional de salud aclara procedimiento de trasplante en Colombia”, 2018. [Online]. A va i l a ble a t : http://www.ins.gov.co/Noticias/Paginas/ElInstituto-Nacional-de-salud-aclaraprocedimiento-de-trasplante-enColombia.aspx\#.WhHsZ7T1XX4.

[18] Diario Oficial de la Unión Europea, "DIRECTIVA (UE) 2015/565 DE LA COMISIÓN. España: por la que se modifica la Directiva 2006/86/CE en lo relativo a determinados requisitos técnicos para la codificación de células y tejidos humano”, 2015, pp. 2-7. [Online] Available at: http://www.ont.es/infesp/Legislacin/DIREC TIVA\%202015\%20565.pdf.

[19] Boletín del Estado, "Legislación Consolidada", España, 2014, pp. 26-31. [Online]. Available at:
http://www.ont.es/infesp/Legislacin/BOEA-2014-7065-consolidado.pdf.

[20] Alcaldía de Bogotá, "Ley 73 de 1998”, 1988. [ $\mathrm{O}$ n l i n e ]. A v a i l a ble a t: http://www.alcaldiabogota.gov.co/sisjur/nor mas/Norma 1.jsp? $i=14524$.

[21] M. López-Lucas, "Manual sobre donación y trasplante de órganos", Enfermería Global, vol. $8, \quad$ n o. $\quad 1, \quad 2009$. https://doi.org/10.6018/eglobal.8.1.50471.

[22] F. Mendoza, "Aspectos ético legales del trasplante de corazón”, Revista Colombiana de Cardiología, vol. 14, no. 5, 2007, pp. 259-275.

[23] Instituto Nacional de Salud, "Informe ejecutivo Red de donación y trasplantes", Bogotá, Colombia, 2015. [Online]. Available at: http://www.consultorsalud.com/sites/consult orsalud/files/informe ejecutivo_red_donacio n_y trasplantes 2015.pdf.

[24] J. Ocharan-Corcuera, "Trasplante renal en España Renal transplant in Spain”, Diálisis y Trasplante, vol. 32, no. 4, 2011, pp. 139-141. https://www.doi.org/10.1016/j.dialis.2011.07 .003 .

[25] L. Reventós, "Agentcities, premio Descartes de la UE por investigar con agentes inteligentes", 2018 . [Online]. Available at: https://elpais.com/diario/2003/11/20/ciberp ais/1069299327_850215.html.

[26] P. Hípola and B. Vargas-Quesada, "Agentes inteligentes: definición y tipología. Los agentes de información”, 1999. [Online]. A v a i l a ble a t : http://www.elprofesionaldelainformacion.co $\underline{\mathrm{m} / \text { contenidos/1999/abril/agentes inteligen }}$ tes definicion y tipologia los agentes de i nformacion.html.

[27] A. Moreno, A. Valls and J. BOCIO, "Gestión de equipos hospitalarios para trasplantes de órganos mediante sistemas multiagentes", Conferencia sobre Inteligencia Artificial en Medicina en Europa, 2001, pp. 374-383. https://doi.org/10.1007/3-540-48229-6 51. 
[28] A. Aldea, B. López, A. Moreno and A. Valls, "Un sistema multiagente para la coordinación de trasplantes de órganos", Conferencia sobre Inteligencia Artificial en Medicina en Europa, 2001, pp. 413-416. https://doi.org/10.1007/3540-48229-6_56.

[29] J. Briceño, et al., "Uso de la inteligencia artificial como un innovador modelo de comparación donante-receptor para el trasplante de hígado: resultados de un estudio multicéntrico en español”, Journal of Hepatology, vol. 61, no. 5, $2014, \quad$ p p. $1020-1028$. https://doi.org/10.1016/j.jhep.2014.05.039.

[30] A. Moreno, "Introducción del editor invitado: sobre la evolución de la aplicación de tecnología de agentes a la atención médica”, IEEE Intelligent Systems, vol. 21, no. 6, 2006, pp. 8-10. https://doi.org/10.1109/MIS.2006.111.

[31] M. Wang, C. Lee, K. Hsieh, C. Hsu, G. Acampora and C. Chang, "Multiagentes basados en ontología para aplicaciones inteligentes de salud", Diario de Inteligencia Ambiental y Computación Humanizada, 2010, pp. 111-131. https://doi.org/10.1007/s12652-010-0011-5.

[32] S. Iqbal, W. Altaf, M. Aslam, W. Mahmood and M. Ghani, "Aplicación de agentes inteligentes en salud: revisión", Revisión de inteligencia artificial, vol. 46, no. 1, 2016, pp. 83-112. https://doi.org/10.1007/s10462-016-9457-y.

[33] N. Betanco-Alvarez and Y. Fernández De la Cruz, "SLD105 Propuesta de arquitectura de sistemas multiagente para el sector sanitario", XV Convención y feria internacional Informática, Cuba, 2013.

[34] C. Esteban, D. Schmidt, D. Krompa and V. Tresp, "Predicción de secuencias de eventos clínicos mediante el uso de un modelo personalizado de inserción latente temporal", International Conference on Healthcare I $\mathrm{n} \mathrm{form} \mathrm{a} \mathrm{ti} \mathrm{c} \mathrm{s} \mathrm{,} \quad 2015$. https://doi.org/10.1109/ICHI.2015.23.

[35] M. Exposito-Gallardo and R. Avila-Avila, "Aplicaciones de la inteligencia artificial en la Medicina: perspectivas y problemas",
ACIMED, vol. 17, no. 5, 2008.

[36] A. Aldea, B. López, A. Moreno, D. Riaño and A. Valls, "Sistema multiagente de soporte a la coordinación de trasplantes", pp. 1-4. Available: https://www.researchgate.net/publication/22 $\underline{8687572 \text { Sistema multiagente de soporte_a }}$ la_coordinacion_de transplantes.

[37] A. Oztekin, D. Delen and Z. Kong, "Predicción de la supervivencia del injerto en pacientes con trasplante de corazón y pulmón: una metodología de minería de datos integrada”, Revista internacional de informática médica, vol. 78, no. 12,2009, p p. 84-96. https://doi.org/10.1016/j.ijmedinf.2009.04.0 $\underline{07}$.

[38] T. Heston, D. Norman, J. Barry, W. Bennett and R. Wilson, "Estratificación del riesgo cardíaco en el trasplante renal mediante una forma de inteligencia artificial", The american journal of cardiology, vol. 79, no. 4, 1997, pp. 415-417. https://doi.org/10.1016/S00029149(96)00778-3.

[39] L. Tong, R. Hoffman, S. Deshpande and M. Wang, "Predecir el rechazo cardíaco mediante el uso de imágenes histopatológicas de diapositivas completas y una red neuronal profunda con abandono", IEEE EMBS International Conference on Biomedical \& Health Informatics (BHI), 2017. https://doi.org/10.1109/BHI.2017.7897190.

[40] P. Quintero, "Comparacion de Metodologias y Arquitecturas de Sistemas Multiagente as en 10 Aplicaciones Utilizadas en Medicina y Servicios de E-salud", 2009. [Online]. A v a i l a b le a t : https://es.scribd.com/document/23897006/C omparacion-de-Metodologias -yArquitecturas-de-Sistemas-Multiagente-asen-10-Aplicaciones-Utilizadas-en-Medicina-yServicios-de-E-salud.

[41] A. Manotas, "Diseño de un sistema multi-agente para monitoreo de redes utilizando JADE y JPCAP”, INGE CUC, vol. 6, no. 1, 2010, pp. 
p. 227-236.

[42] M. Ubilla, S. Mastrobuoni, A. MartínArnau, A. Cordero, E. Alegría, J. Gavira, M. Iribarren, T. Rodríguez-Fernández, J. Herreros and G. Rábago, "Trasplante cardíaco", Anales del Sistema Sanitario de Navarra, vol. 29, no. 2, 2006

[43] Ministerio de salud y protección social, "Biblioteca Digital - RIDE", 2013. [O n l in e ]. A vail a ble a t: https://www.minsalud.gov.co/sites/rid/Lists/Bibl iotecaDigital/Forms/tienda\%20terminos.aspx?Ro otFolder $=\% 2$ fsites\%2frid\%2fLists \%2fBibliotecaDi gital\%2fRIDE\&FolderCTID=0x012000D4CDD6 1CAE671A41B3532ECA51ACD38E. 